\title{
Evaluation of Potato (Solanum tuberosum L.) Genotypes for Yield and Tuber Quality Related Traits at Lowland, Dire Dawa, Eastern Ethiopia
}

\author{
Wassu Mohammed* and Simeret Burga
}

\author{
School of Plant Sciences, Haramaya University, P.O. Box: 138, Dire Dawa, Ethiopia
}

\section{Abstract}

Potato (Solanum tuberosum L.) produces more nutritious food on less land with short period of time, but the production in lowland areas is limited by high temperatures, because the crop is adapted to cool climates and perform best at about $20^{\circ} \mathrm{C}$. The production of potato at lowland areas demands to develop heat tolerant cultivars adaptable specific to high temperatures. Therefore, this research was conducted with the objectives of evaluating the yield and tuber quality related traits of 26 potato genotypes and estimating the genetic diversity under heat stress. The experiment was conducted at Dire Dawa in 2012 during the hottest months with $>26^{\circ} \mathrm{C}$ and $>33^{\circ} \mathrm{C}$ daily average and highest temperatures, respectively. Genotypes were planted in Randomized Block Design with three replications. The presence of significant differences among potato genotypes were observed for 12 tuber yield and tuber quality related traits. The genotypes produced 7.41 to 24.3 and 4.44 to $22.52 \mathrm{t} \mathrm{ha}^{-1}$ total and marketable tuber yields, respectively, with tuber dry matter content ranged from 14.89 to $20.96 \%$. The highest yields and tuber dry matter content were obtained from heat tolerant genotype (Vivadial). Heritability and expected genetic advance ranged from 22.35 to 87.65 and 15.24 to $54.97 \%$, respectively, while genotypic and phenotypic coefficient of variations ranged from 13.63 to 85.54 and 16.78 to $90.97 \%$, respectively. All the variability components values were medium to high for all traits suggested that selection genotypes on the basis of their performance was effective method to improve the crop in lowland areas. The genotypes were clustered in three groups of which Cluster I and II consisting of 11 and 14 genotypes, respectively, while Vivadial formed solitary Cluster III. The research results demonstrated the existence of wider genetic variations among the potato genotypes and the higher chance of developing cultivars adaptable to lowland areas.
\end{abstract}

Copyright@2015 STAR Journal, Wollega University. All Rights Reserved.
Article Information Article History:

Received : 15-07-2015

Revised : 30-08-2015

Accepted : 13-09-2015

Keywords:

Cluster

Heat tolerant

Genetic variability

Genotypes

Variability components

${ }^{*}$ Corresponding Author:

Wassu Mohammed

E-mail:

wasmoha@yahoo.com

\section{INTRODUCTION}

Potato (Solanum tuberosum L.) is highly recommended food security crop for low-income farmers and vulnerable consumers. It is one of the plant species that are the most effective in transforming the solar energy into human food (Kalaji et al., 2011; Brestic et al., 2012; Bahari et al., 2013). The potato is producing up to $85 \%$ of the plant part as edible human food compared to about $50 \%$ in cereals (FAO, 2009). The plant potato produces more nutritious food more quickly, on less land, and relatively harsher climates than any other major crops. Potato is major economic importance crop and number one non-grain food commodity in the world (Rykaczewska, 2013). It is the third most important food crop in terms of consumption in the world after rice and wheat (Birch et al., 2012; Hancock et al., 2014).

The Eastern Africa has over 200 million people and expected to be doubled by 2030 . For this region food security is a key priority that puts increasing pressure on the fixed land for food production to feed the increasing population. This is further aggravated by the increasingly degraded environment and the uncertainties resulting from climate change. For such conditions robust crops that can adapt to a wide range of agro-ecologies in the region are required of which potato, sweet potato and cassava are the major food staple crops in the Eastern Africa countries (Kyamanywa et al., 2011). However, the production of potato in the tropics and subtropics is mainly limited by heat and water stresses, because the plant is adapted typical for temperate/cool climate and does not perform well in areas with high temperatures (Koman and Haverkort, 1995; Hijmans, 2003). It develops and produced tubers best at temperatures of about $20^{\circ} \mathrm{C}$ (Struik et al., 1989; Rykaczewska, 1993; Van Dam et al., 1996). Although potato is extensively adapted in temperate/cool climates certain genotypes have the capacity to initiate tubers at high temperatures (Ewing et al., 1987) and exhibit relatively small yield losses in hot seasons (Levy, 1986). Therefore, developing potato cultivars to high temperatures of the tropics is an important task of breeders, since in vast areas of tropical Africa, the yielding capacity and the high nutritional value of the potato is much needed.

Eastern Ethiopia is one of the four major potato growing areas in the country. The eastern Ethiopia potato production is mainly covers the eastern highlands, especially East Hararghe zone (CSA, 2009). The most 
Wassu Mohammed and Simeret Burga

important feature of potato production in this region is that the potato produced is market oriented with considerable amount being exported to Djibouti and Somalia (Adane et al., 2010). The larger proportion of land in eastern Ethiopia is lowland but suitable for crops production as far as water is available for irrigation. Therefore, extending of potato production to lowlands areas of eastern Ethiopia in particular and in Ethiopia in general is appropriate strategy to exploit the advantage of the crop for food and nutrition security and to increase foreign currency earnings. However, the production of potato at lowland areas is demanding the availability of heat tolerant varieties. Searching genotypes tolerant to heat is not only for potato, but also important within all crop species due to global warming heat stress is an agricultural problem in many areas in the world (Arvin and Donnelly, 2008; Birch et al., 2012).

The potato varieties recommended for production in Ethiopia are for middle to highland areas. These varieties might not produce reasonable yield and quality tubers at lowland since tuberization is significantly inhibited and photoassimilate partitioning to tubers is greatly reduced under high-temperature conditions (Ewing, 1981; Krauss and Marschner, 1984; Haynes et al., 1989; Lafta and Lorenzen, 1995; Van Dam et al., 1996; Rykaczewska, 2015). However, there are reports that indicate the existence of genetic variability for heat tolerance (Tai and
Sci. Technol. Arts Res. J., July-Sep 2015, 4(3): 1-10

Coleman, 1999), which could be exploited in breeding programs. Haramaya University has been introduced some heat tolerant potato cultivars and tested at lowland area along with many other genotypes. However, agronomic performance, and genetic diversity of genotypes under heat stress is not well studied. Therefore, this study was re-initiated with the objectives of evaluating the yield and tuber quality related traits performance of genotypes and estimating genetic diversity under heat stress.

\section{MATERIALS AND METHODS}

\section{Description of the Study Area}

The field experiment was conducted at Dire Dawa Agricultural Research Station of Haramaya University during the hottest months (June-October) of 2012 (Table 1). Dire Dawa is located between latitude and longitude of $9^{3} 36^{\prime} \mathrm{N}$ and $41^{\circ} 52^{\prime} \mathrm{E}$ coordinates. The altitude of Dire Dawa is 1260 meters above sea level (Hailay et al., 2004) and the mean annual temperatures range from $21.5^{\circ} \mathrm{C}$ (December) to $28.4^{\circ} \mathrm{C}$ (June).

\section{Experimental Materials}

A total of 26 genotypes were evaluated of which five were heat tolerant and one recently released potato variety, Bubu (Table 2).

Table 1: Weather data of Dire Dawa

\begin{tabular}{lccccc}
\hline Month & $\begin{array}{c}\text { Average } \\
\text { high }{ }^{\circ} \mathbf{C}\end{array}$ & $\begin{array}{c}\text { Daily } \\
\text { mean }\end{array}{ }^{\circ} \mathbf{C}$ & $\begin{array}{c}\text { Average } \\
\text { low }{ }^{\circ} \mathbf{C}\end{array}$ & $\begin{array}{c}\text { Average } \\
\text { rainfall }(\mathbf{m m})\end{array}$ & $\begin{array}{c}\text { Average } \\
\text { relative humidity (\%) }\end{array}$ \\
\hline January & 27.2 & 22.1 & 14 & 15 & 43.9 \\
February & 28 & 23.1 & 15.5 & 33 & 49.8 \\
March & 30 & 25.7 & 16.3 & 67 & 45 \\
April & 29 & 26.2 & 20 & 103 & 47 \\
May & 31 & 27.6 & 21.3 & 55 & 39.3 \\
June & 33.5 & 28.4 & 22.4 & 20 & 37.6 \\
July & 32 & 27.1 & 20.6 & 80 & 41.4 \\
August & 31 & 26.1 & 20.1 & 117 & 45.1 \\
September & 29.9 & 26.5 & 20.5 & 60 & 39.7 \\
October & 28.5 & 25.7 & 19.5 & 19 & 31.3 \\
November & 27.5 & 22.9 & 15.7 & 17 & 39.1 \\
December & 27 & 21.5 & 15 & 8 & 42.6 \\
\hline \multicolumn{7}{c}{ Year } & $\mathbf{2 9 . 5 5}$ & $\mathbf{2 5 . 2 4}$ & $\mathbf{1 8 . 4 1}$ & $\mathbf{5 9 4}$ & $\mathbf{4 1 . 8 2}$ \\
\hline \multicolumn{5}{r}{ Source: Levoyageur Weather (2012). }
\end{tabular}

Table 2: List of potato genotypes evaluated at Dire Dawa in 2012

\begin{tabular}{ccccc}
\hline No. & Genotype & No. & Genotype & Remark \\
\hline 1 & CIP-392640-516 & 14 & AL-100 & \\
2 & CIP-392640-541 & 15 & AL-348 & \\
3 & CIP-392640-528 & 16 & AL-503 & \\
4 & CIP-386029-18c & 17 & AL-209 & \\
5 & CIP-392140-526 & 18 & AL-269 & Genotypes with initial AL are the old potato accessions introduced \\
6 & CIP-392640-525 & 19 & AL-119 & before 1975 while with CIP initial were introduced from International \\
7 & CIP-378371-9c & 20 & AL-270 & Center for Potato (CIP) at different periods. \\
8 & CIP-378323-2B & 21 & HU19 & \\
9 & CIP-378501-10A & 22 & HU16 & Genotypes with initial HU were introduced at different periods as heat \\
10 & CIP-391058-506 & 23 & HU1 & tolerant accessions but information is not available. \\
11 & CIP-391058-520 & 24 & HU14 & \\
12 & CIP-392037-500 & 25 & Vivadial & Heat tolerant accession \\
13 & CIP-378371-19 & 26 & Bubu & Released in 2011 for mid to highland areas \\
\hline
\end{tabular}


Wassu Mohammed and Simeret Burga

\section{Experimental Design}

The experiment was laid out as a Randomized Complete Block Design (RCBD) where each genotype was replicated three times. Each plot was $3.60 \times 4.50 \mathrm{~m}$ $\left(16.2 \mathrm{~m}^{2}\right)$ consisting of six rows, that contained a total of 12 plants per row and 72 plants per plot. The spacing between plots and adjacent replications were 1.0 and 1.5 $\mathrm{m}$, respectively.

Medium-sized and well sprouted potato tubers were planted at the spacing of $75 \mathrm{~cm}$ between rows and $30 \mathrm{~cm}$ between plants. The planting depth was maintained at 5 to $10 \mathrm{~cm}$. The whole recommended rate of Phosphorus fertilizer $\left(92 \mathrm{~kg} \mathrm{P}_{2} \mathrm{O}_{5} \mathrm{ha}^{-1}\right)$ was applied at planting in the form of Diammonium Phosphate. Nitrogen fertilizer was applied at the rate of $75 \mathrm{~kg} \mathrm{~N}^{-1}$ in the form of Urea in two splits, half rate after full emergence (two weeks after planting) and half rate at the initiation of tubers. The irrigation water is applied every three days and all agronomic practices were applied as per the recommendation made by the Haramaya University for the region.

\section{Data Collection}

Days to $50 \%$ of plants flowering was recorded as the number of days of planting to $50 \%$ of the plants produced flowers in each plot. Plant height was measured from 10 randomly selected plants in the central rows during $50 \%$ of the plants attained physiological maturity in each plot. The total tuber yield of each genotype was taken from plants in the four middle rows. Tubers were carefully collected after the hills were dug by hand. The collected total tubers in each plot were weighted and converted to tons per hectare. Tubers which were free from diseases, insect pests, and greater than or equal to $20 \mathrm{~g}$ in weight were sorted, and weighed for each plot and converted as marketable yield $\left(\mathrm{t} \mathrm{ha}^{-1}\right)$. The remaining tubers (diseased, insect-attacked and small-sized, i.e. $<20 \mathrm{~g}$ ) were recorded as unmarketable tuber yield $\left(\mathrm{t} \mathrm{ha}^{-1}\right)$. Percent marketable and unmarketable tuber yields were calculated as proportion of the two yields to total tuber yield. Number of total, marketable, and unmarketable tubers were divided by the number of harvested plants and recorded as number of tubers per plant.

Tuber dry matter content (\%) was measured from five fresh tubers in each plot. The randomly selected tubers were weighed at harvest, sliced and dried in oven at $75^{\circ} \mathrm{C}$ until a constant weight was attained and dry matter in percent was calculated according to Williams and Woodbury (1968) as follows.

$$
\text { Dry matter }(\%)=\frac{\text { Weightof sampleafterdrying }(g)}{\text { Intialweightof sample }(g)} \times 100
$$

Total starch content $(\mathrm{g} / 100 \mathrm{~g})$ was estimated from dry matter content. Starch content $(\mathrm{g} / 100 \mathrm{~g})=17.55+0.891$ * (tuber dry weight $\%-24.182$ ) (AOAC, 1980) where dry matter content was determined as indicated above. The total starch yield was recorded as the multiple of starch content and total yield $\mathrm{t} \mathrm{ha}{ }^{-1}$.

\section{Data Analysis}

Data collected for 13 traits were subjected to analysis of variance which was computed with SAS statistical software (9.1). Phenotypic and genotypic variance, coefficient of variation, heritability, and genetic advance were computed using the excel microsoft program. Mean separation was employed following the significance of
Sci. Technol. Arts Res. J., July-Sep 2015, 4(3): 1-10

mean squares using Least Significant Differences (LSD) at $5 \%$ probability. Euclidean distances depicting genetic relationships among 26 potato genotypes based on 12 traits and dendrogram was generated based on Unweighted Pair-group Method with Arithmetic means (UPGMA) were computed using STATISTICA-7 basic statistical analysis software (U.S.A.).

The phenotypic and genotypic variances and coefficients of variations were estimated according to the methods suggested by Burton and Devane (1953). Heritability $\left(\mathrm{H}^{2}\right)$ in broad sense was computed using the formula adopted by Allard (1960) and Falconer (1990), and genetic advance (GA) for each trait was computed using the formula adopted by Johnson et al. (1955) and Allard (1960) as follows:

$$
\sigma_{g}^{2}=M_{g}-M_{e} / r \text { and } \sigma_{p}^{2}=\sigma_{g}^{2}-\sigma_{e}^{2}
$$

where; $\sigma_{p}^{2}=$ phenotypic variance, $\sigma_{g}^{2}=$ genotypic variance, $\sigma^{2} e$ environmental variance/error mean square, $M_{g}=$ mean square of genotypes, and $M_{e}=$ mean square of error, $r=$ number of replications. Phenotypic coefficient of variation $(\mathrm{PCV})=\frac{\sqrt{\sigma^{2} p}}{x} x 100$ and genotypic coefficient of variation, $\mathrm{GCV}=\frac{\sqrt{\sigma^{2} g}}{x} x 100$ were also calculated where $\mathrm{x}=$ population mean.

Heritability in broad sense was computed as $\mathrm{H}^{2}=\left[\sigma^{2}{ }_{\mathrm{g}} /\right.$ $\left.\sigma^{2}{ }_{p}\right] \times 100$, where; $H^{2}$ is heritability in broad sense, $\sigma^{2}{ }_{g}=$ genotypic variance, and $\sigma{ }^{2} p=$ phenotypic variance. Genetic advance as part of the mean (GA) for each trait was computed as $G A=(k)\left(\sigma_{p}\right)^{*}\left(H^{2}\right)$, and GAM (genetic advance as $\%$ of the mean $)=\frac{G A}{\bar{X}} \times 100$ where $\mathrm{k}=$ selection differential $\left(\mathrm{k}=2.06\right.$ at $5 \%$ selection intensity), $\sigma_{\mathrm{p}}=$ phenotypic standard deviation, $\mathrm{H}^{2}=$ heritability in broad sense, and $x=$ grand mean of each trait.

Genetic distance of 26 potato genotypes was estimated using Euclidean distance (ED) calculated from the 12 traits after standardization (subtracting the mean value and dividing it by the standard deviation) as established by Sneath and Sokal, (1973) as follows:

$$
\mathrm{ED}_{\mathrm{jk}}=\sqrt{\sum_{i=1}^{n}\left(X_{i j}-X_{i k}\right)^{\frac{2}{2}}}
$$

Where, $E D_{j k}=$ distance between genotypes $\mathrm{j}$ and $\mathrm{k} ; \mathrm{x}_{\mathrm{ij}}$ and $x_{i k}=$ phenology, growth, tuber yield and tuber quality related traits mean values of the ith trait for genotypes $j$ and $\mathrm{k}$, respectively; and $\mathrm{n}=$ number of traits used to calculate the distance. The distance matrix from tuber phenology, growth, yield and tuber quality related traits was used to construct dendrograms based on the Unweighted Pair-group Method with Arithmetic means (UPGMA). The results of the cluster analysis were presented in the form of dendrogram. In addition, mean average distance (ED) was calculated for each genotype by averaging the distance of a particular potato genotype over the other 25 genotypes. The calculated average distance was used to estimate which potato genotype is closest or distant to the others.

\section{RESULTS}

\section{Analysis of Variance}

The mean squares from analysis of variance for 13 traits of 26 potato genotypes are presented in Table 3 . The results revealed the presence of significant differences among potato genotypes for all traits except for number of unmarketable tuber/plant. 
Table 3. Mean squares from analysis of variance for 13 traits of 26 potato genotypes

\begin{tabular}{|c|c|c|c|c|}
\hline Trait & Replication (2) & Genotype (25) & Error (50) & CV (\%) \\
\hline Days to $50 \%$ flowering & 2.705 & $39.68^{\star *}$ & 2.74 & 4.3 \\
\hline Plant height $(\mathrm{cm})$ & 9.00 & $124.88^{* *}$ & 7.60 & 4.8 \\
\hline Total tuber yield $\mathrm{t} \mathrm{ha}^{-1}$ & 210.73 & $56.15^{\star}$ & 23.35 & 22.1 \\
\hline Marketable tuber yield $\mathrm{t} \mathrm{ha}^{-1}$ & 271.96 & $66.35^{\star *}$ & 21.20 & 20.5 \\
\hline Unmarketable tuber yield $\mathrm{t} \mathrm{ha}^{-1}$ & 1.79 & $2.024^{* *}$ & 0.59 & 20.6 \\
\hline Total tuber number/plant & 0.31 & $3.03^{* *}$ & 0.16 & 6.0 \\
\hline Number of marketable tuber /plant & 0.08 & $3.79^{* *}$ & 0.17 & 10.6 \\
\hline Number of unmarketable tuber/plant & 1.33 & 2.51 & 1.63 & 28.5 \\
\hline Percent marketable tuber yield (\%) & 207.67 & $379^{* *}$ & 131.50 & 17.7 \\
\hline Percent unmarketable tuber yield (\%) & 103.76 & $92.1^{* *}$ & 38.60 & 16.4 \\
\hline Tuber dry matter content $(\%)$ & 6.79 & $43.23^{* *}$ & 2.31 & 8.5 \\
\hline Starch content $(\mathrm{g} / 100 \mathrm{~g})$ & 5.39 & $32.26^{* *}$ & 1.83 & 11.4 \\
\hline Starch total yield $\mathrm{t} \mathrm{ha}{ }^{-1}$ & 1.258 & $1.034^{* *}$ & 0.16 & 19.8 \\
\hline
\end{tabular}

\section{Mean Performance of Genotypes}

The 26 potato genotypes exhibited a wide range of mean values for all traits. The genotypes total tuber yield was ranged from 7.4 to $24.3 \mathrm{t} \mathrm{ha}^{-1}$ (Table 4) with the overall mean total tuber yield of $12.89 \mathrm{t} \mathrm{ha}^{-1}$ (Table 5), whereas marketable and unmarketable tuber yields were ranged from 4.44 to 22.52 and 0.62 to $3.85 \mathrm{t} \mathrm{ha}^{-1}$, respectively. The proportion of marketable and unmarketable tuber yields were also exhibited wide variations that ranged between 48.95 and 94.08 and 5.93 and $51.22 \%$, respectively. Tuber dry matter and starch contents of genotypes ranged from 14.89 to $20.96 \%$ and 9.27 to $20.96 \mathrm{~g} / 100 \mathrm{~g}$, respectively, whereas total starch yield ranged from 0.79 to $3.44 \mathrm{t} \mathrm{ha}^{-1}$ (Table 4). The variations among the 26 potato genotypes were also large for other traits. The highest total and marketable tuber yields as well as total starch yield $\mathrm{t} \mathrm{ha}^{-1}$ were obtained from Vivadial (heat tolerant genotype).

The four heat tolerant genotypes other than Vivadial produced 11.26 to 17.18 and 7.41 to $16 \mathrm{t} \mathrm{ha}^{-1}$ total and marketable tuber yield, respectively (Table 4). Two potato genotypes produced total and marketable tuber yield more than the four heat tolerant genotypes. The improved potato variety (Bubu) produced total and marketable tuber yield lower than heat tolerant genotypes and other five genotypes. The heat tolerant genotypes were early flowering than most of the other genotypes.

\section{Variability Components}

The phenotypic and genotypic coefficient of variations ranged between 16.78 and 90.97 and 13.63 and $85.54 \%$, respectively. Both highest phenotypic and genotypic coefficient of variations were computed for starch content of tubers while the lowest phenotypic and genotypic coefficient of variations were recorded for total number of tubers per plant and unmarketable tuber yield $\mathrm{t} \mathrm{ha}^{-1}$, respectively (Table 5). The phenotypic coefficient of variation was higher than genotypic coefficient of variation for all traits.

The estimated heritability value was highest for marketable number of tubers per plant $(87.65 \%)$ while the lowest was computed for unmarketable tuber yield $\mathrm{t} \mathrm{ha}^{-1}$ $(22.35 \%)$. The heritability in broad sense values were $>31 \%$ for the remaining 10 traits. The genetic advance as percent mean values ranged from 15.24 to $54.97 \%$ for all traits. The lowest and highest genetic advance values were recorded for percent marketable tuber yield and marketable number of tubers per plant, respectively.

\section{Genetic Distance of Potato Genotypes}

Estimates of genetic distance measured from Euclidean distance varied from 1 to 10.1 with mean and standard deviation of 4.63 and 1.61 , respectively. The highest genetic distance was registered for Vivadial and CIP-386029-18c followed by Vivadial and CIP-391058506 as well as Vivadial and Al-100 (9). The lowest distance was calculated for Al-100 and CIP-386029-18c, followed by CIP-392640-516 and CIP-378501-10A (1.04), Al-269 and HU14 (1.2), CIP-392640-516 and HU1 (1.36). The mean Euclidean distance result showed that the closest genotypes to others were CIP-378501-10A (3.55) followed by CIP-392640-516 (3.74) and HU1 (3.81) while the most distant to others were Vivadial (7.38) followed by HU19 (5.41) and CIP-386029-18c (5.37). Vivadial had Euclidean distance $<5.34$ only with HU16 and CIP392140-526 (Table 6). Among 325 pairs of genotypes 177 and 148 pairs had $<4.63$ and $\geq 4.63$ distances, respectively.

The dendrogram constructed from Unweighted Pairgroup Method with Arithmetic means (UPGMA) based on the Euclidean distance matrix is presented in Figure 1. Clustering resulted in the formation of three major groups of genotypes, of which Cluster I comprised 11 genotypes and Cluster II consisted of 14 hat subdivided in to two of which Subgroup I and II consisted of 6 and 8 genotypes, respectively. Vivadial formed a solitary Cluster III while the other four heat tolerant genotypes were distributed in two clusters. None of the old potato accessions (with initial AL-) grouped in Cluster I rather distributed in the two subgroups of cluster II. Bubu (improved variety) was grouped in Cluster I with one heat tolerant accession (HU16).

Cluster I was characterized by higher mean performance than overall mean of genotypes except for unmarketable tuber yield ( $\mathrm{t} \mathrm{ha}^{-1}$ ) and percent unmarketable tuber yield which was desired in selection of genotypes. The members of this cluster had total and marketable tuber yield of 12.77 to 21.63 and 11.25 to $19.85 \mathrm{t} \mathrm{ha}^{-1}$, respectively. Cluster II was characterized by 


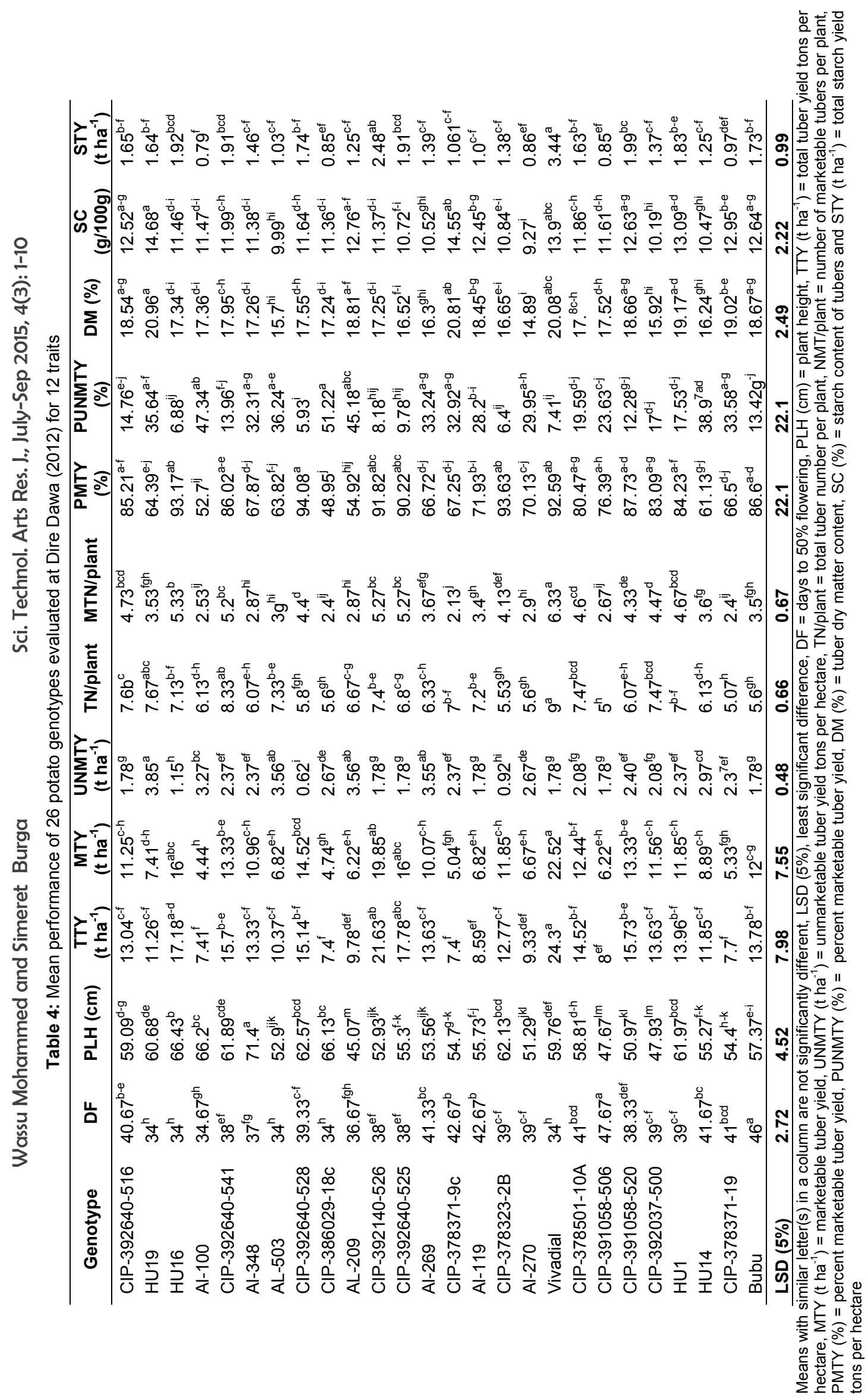


Table 5: Variability components for 12 traits of 26 potato genotypes evaluated at Dire Dawa (2012)

\begin{tabular}{|c|c|c|c|c|c|c|c|c|c|}
\hline Trait & Mean & Minimum & Maximum & $\mathbf{G V}$ & PV & GCV & PCV & $\mathrm{H}_{2}(\%)$ & GAM (5\%) \\
\hline DF & 38.87 & 34 & 47.67 & 12.31 & 15.06 & 31.67 & 38.73 & 81.77 & 16.81 \\
\hline PLH $(\mathrm{cm})$ & 57.39 & 45.07 & 71.4 & 39.09 & 46.69 & 68.12 & 81.36 & 83.72 & 20.54 \\
\hline TTY $\left(\mathrm{t} \mathrm{ha}^{-1}\right)$ & 12.89 & 7.4 & 24.3 & 8.17 & 21.82 & 63.34 & 69.22 & 37.43 & 27.94 \\
\hline $\operatorname{MTY}\left(\mathrm{t} \mathrm{ha}^{-1}\right)$ & 10.62 & 4.44 & 22.52 & 5.05 & 16.25 & 47.55 & 53.01 & 31.08 & 24.3 \\
\hline UNMTY (t ha-1) & 2.29 & 0.62 & 3.85 & 0.31 & 1.4 & 13.63 & 60.95 & 22.35 & 23.73 \\
\hline TN/plant & 6.65 & 5 & 9 & 0.96 & 1.12 & 14.38 & 16.78 & 85.67 & 28.03 \\
\hline MTN/plant & 3.85 & 2.13 & 6.33 & 1.21 & 1.38 & 31.31 & 35.72 & 87.65 & 54.97 \\
\hline PMTY (\%) & 76.2 & 48.95 & 94.08 & 82.5 & 114.04 & 58.25 & 80.79 & 38.55 & 15.24 \\
\hline PUNMTY (\%) & 23.9 & 5.93 & 51.22 & 17.83 & 56.43 & 24.6 & 36.07 & 31.6 & 20.46 \\
\hline DM (\%) & 17.79 & 14.89 & 20.96 & 13.64 & 15.95 & 76.66 & 89.62 & 85.53 & 39.54 \\
\hline$S C(g / 100 g)$ & 11.86 & 9.27 & 14.68 & 10.14 & 11.97 & 85.54 & 90.97 & 84.72 & 50.92 \\
\hline $\operatorname{STY}\left(\mathrm{t} \mathrm{ha}^{-1}\right)$ & 1.51 & 0.793 & 3.435 & 0.22 & 0.59 & 14.79 & 38.69 & 38.23 & 39.8 \\
\hline
\end{tabular}

$\mathrm{GV}=$ genetic variance, $\mathrm{PV}=$ phenotypic variance, GCV = genetic coefficient of variation, $\mathrm{PCV}=$ phenotypic coefficient of variation, $\mathrm{H} 2$ (\%) = heritability in broad sense, GAM $(5 \%)=$ genetic advance as percent mean at $5 \%$ selection intensity, DF $=$ days to $50 \%$ flowering, PLH $(\mathrm{cm})=$ plant height, TTY $\left(\mathrm{t}\right.$ ha $\left.{ }^{-1}\right)=$ total tuber yield tons per hectare, $\mathrm{MTY}\left(\mathrm{t} \mathrm{ha} \mathrm{a}^{-1}\right)=$ marketable tuber yield, UNMTY $\left(\mathrm{t} \mathrm{ha}^{-1}\right)=$ unmarketable tuber yield tons per hectare, $\mathrm{TN} /$ plant $=$ total tuber number per plant, NMT/plant $=$ number of marketable tubers per plant, PMTY $(\%)=$ percent marketable tuber yield, PUNMTY $(\%)=$ percent marketable tuber yield, DM $(\%)=$ tuber dry matter content, SC $(\%)=$ starch content of tubers and STY $\left(\mathrm{t} \mathrm{ha}{ }^{-1}\right)=$ total starch yield tons per hectare.

Table 6: Euclidean distance of 26 potato genotypes measured from 12 traits and mean Euclidean distance obtained by averaging each genotype distance to other 25 potato genotypes as evaluated at Dire Dawa in 2012

\begin{tabular}{|c|c|c|c|c|c|c|c|c|c|c|c|c|c|}
\hline Genotype & $\begin{array}{c}\text { HU1 } \\
9\end{array}$ & $\begin{array}{c}\text { HU1 } \\
6\end{array}$ & $\begin{array}{l}\text { Al- } \\
100\end{array}$ & $\begin{array}{c}\text { CIP- } \\
392640- \\
541\end{array}$ & $\begin{array}{c}\text { Al- } \\
348\end{array}$ & $\begin{array}{l}\text { AL- } \\
503\end{array}$ & $\begin{array}{c}\text { CIP- } \\
39264- \\
528\end{array}$ & $\begin{array}{c}\text { CIP- } \\
386029- \\
18 c\end{array}$ & $\begin{array}{l}\text { AL- } \\
209\end{array}$ & \multicolumn{2}{|c|}{$\begin{array}{c}\text { CIP- } \\
392140- \\
526\end{array}$} & $\begin{array}{c}\text { CIP- } \\
392640- \\
525\end{array}$ & $\begin{array}{l}\text { Al- } \\
269\end{array}$ \\
\hline $\begin{array}{l}\text { CIP-392640-516 } \\
\text { (3.74) }\end{array}$ & 4.63 & 3.13 & 5.60 & 1.74 & 3.87 & 5.07 & 2.85 & 5.9 & 5.10 & \multicolumn{2}{|c|}{3.59} & 2.83 & 4.02 \\
\hline HU19 & & 6.33 & 4.53 & 4.78 & 4.76 & 5.24 & 6.65 & 5.1 & 3.67 & \multicolumn{2}{|c|}{6.80} & 6.45 & 5.22 \\
\hline HU16 & & & 6.76 & 2.57 & 4.32 & 6.11 & 2.41 & 6.9 & 7.13 & \multicolumn{2}{|c|}{2.98} & 2.36 & 5.54 \\
\hline Al-100 & & & & 5.97 & 3.13 & 3.26 & 6.59 & 1.0 & 3.81 & \multicolumn{2}{|c|}{7.85} & 6.64 & 3.99 \\
\hline CIP-392640-541 & & & & & 4.07 & 5.03 & 3.53 & 6.4 & 5.67 & \multicolumn{2}{|c|}{2.97} & 2.53 & 4.25 \\
\hline Al-348 & & & & & & 4.08 & 4.12 & 3.2 & 4.98 & \multicolumn{2}{|c|}{5.60} & 4.52 & 3.55 \\
\hline AL-503 & & & & & & & 6.24 & 3.7 & 3.46 & \multicolumn{2}{|c|}{6.39} & 5.22 & 2.69 \\
\hline CIP-392640-528 & & & & & & & & 6.6 & 6.78 & \multicolumn{2}{|c|}{3.57} & 2.58 & 5.12 \\
\hline CIP-386029-18c & & & & & & & & & 4.13 & \multicolumn{2}{|c|}{$\begin{array}{l}8.01 \\
6.03\end{array}$} & 6.79 & 4.37 \\
\hline AL-209 & & & & & & & & & & \multicolumn{2}{|c|}{6.93} & 6.21 & 3.54 \\
\hline CIP-392140-526 & & & & & & & & & & & & 1.84 & 5.21 \\
\hline CIP-392640-525 & & & & & & & & & & & & & 4.11 \\
\hline \multirow[t]{2}{*}{ Mean ED } & 5.41 & 4.84 & 5.16 & 4.16 & 4.30 & 4.83 & 4.50 & 5.37 & 5.00 & \multicolumn{2}{|c|}{5.11} & 4.29 & 4.11 \\
\hline & $\begin{array}{c}\text { CIP- } \\
378371 \\
-9 c\end{array}$ & Al-119 & $\begin{array}{c}\begin{array}{c}\text { CIP- } \\
378323 \\
-2 B\end{array} \\
\end{array}$ & Al-270 & Vivadial & $\begin{array}{c}\text { CIP- } \\
378501 \\
-10 A\end{array}$ & $\begin{array}{cc}\begin{array}{c}\text { CIP- } \\
1 \\
391058\end{array} \\
\end{array}$ & $\begin{array}{c}\begin{array}{c}\text { CIP- } \\
391058\end{array} \\
-520\end{array}$ & $\begin{array}{c}\begin{array}{c}\text { CIP- } \\
392037\end{array} \\
-500\end{array}$ & HU1 & HU14 & $\begin{array}{c}\text { CIP- } \\
378371 \\
-19\end{array}$ & Bubu \\
\hline CIP-392640-516 & 4.4 & 2.67 & 3.18 & 5.2 & 5.6 & 1.04 & 4.79 & 2.45 & 3.12 & 1.36 & 4.14 & 4.47 & 2.73 \\
\hline HU19 & 3.73 & 4.53 & 6.78 & 6.74 & 7.2 & 4.75 & 6.82 & 4.81 & 6.2 & 3.82 & 5.38 & 4.59 & 5.72 \\
\hline HU16 & 7.04 & 5.29 & 3.02 & 6.25 & 4.9 & 3.16 & 6.95 & 3.7 & 4.17 & 3.2 & 5.71 & 6.54 & 4.67 \\
\hline Al-100 & 4.79 & 4.22 & 5.94 & 4.08 & 9.9 & 5.23 & 5.62 & 5.99 & 5.75 & 5.29 & 3.47 & 3.64 & 6.05 \\
\hline CIP-392640-541 & 5.65 & 4.03 & 3.9 & 5.71 & 4.7 & 1.65 & 6.18 & 3 & 3.31 & 1.93 & 4.62 & 5.7 & 4.04 \\
\hline Al-348 & 5.05 & 3.79 & 3.79 & 4.25 & 7.7 & 3.41 & 5.31 & 4.37 & 4.65 & 3.47 & 3.27 & 3.98 & 4.19 \\
\hline AL-503 & 5.69 & 4.27 & 5.51 & 2.68 & 9 & 4.47 & 5.46 & 5.12 & 3.64 & 5.16 & 2.75 & 4.63 & 5.97 \\
\hline CIP-392640-528 & 6.15 & 4.37 & 1.41 & 5.49 & 6.2 & 2.95 & 5.19 & 3.14 & 3.95 & 3.16 & 5.1 & 5.33 & 2.96 \\
\hline CIP-386029-18c & 5.08 & 4.46 & 5.91 & 4.16 & 10.1 & 5.53 & 5.65 & 6.2 & 5.98 & 5.61 & 3.68 & 3.67 & 6.18 \\
\hline AL-209 & 3.63 & 3.75 & 6.48 & 4.47 & 8.9 & 4.82 & 4.86 & 4.7 & 4.92 & 4.89 & 3.52 & 3.2 & 5.46 \\
\hline CIP-392140-526 & 7.37 & 5.75 & 4.31 & 6.5 & 4 & 3.3 & 6.87 & 3.08 & 3.71 & 3.78 & 5.71 & 7 & 4.55 \\
\hline CIP-392640-525 & 6.71 & 4.7 & 2.82 & 5 & 5.4 & 2.39 & 5.7 & 2.63 & 2.44 & 3.2 & 4.48 & 5.93 & 3.84 \\
\hline Al-269 & 5.11 & 3.51 & 4.59 & 2.62 & 8.2 & 3.2 & 4.07 & 3.8 & 3.03 & 4.04 & 1.12 & 3.86 & 4.09 \\
\hline CIP-378371-9c & & 2.69 & 6.1 & 5.94 & 8.8 & 4.67 & 4.29 & 4.92 & 5.9 & 4.31 & 4.87 & 2.61 & 4.31 \\
\hline Al-119 & & & 4.06 & 4.08 & 8 & 2.72 & 3.11 & 3.82 & 3.65 & 3.21 & 3.13 & 2.6 & 3.14 \\
\hline CIP-378323-2B & & & & 4.44 & 7.3 & 3.12 & 4.58 & 3.49 & 3.51 & 3.58 & 4.48 & 4.88 & 3.19 \\
\hline Al-270 & & & & & 9.8 & 4.6 & 3.76 & 5.06 & 3.42 & 5.51 & 2.27 & 4.07 & 5.1 \\
\hline Vivadial & & & & & & 5.81 & 9.9 & 5.59 & 7.1 & 5.34 & 8.65 & 9.28 & 7.08 \\
\hline CIP-378501-10A & & & & & & & 4.63 & 2.42 & 2.57 & 1.67 & 3.39 & 4.41 & 2.76 \\
\hline CIP-391058-506 & & & & & & & & 4.74 & 4.56 & 5.22 & 3.69 & 2.85 & 3.34 \\
\hline CIP-391058-520 & & & & & & & & & 3.27 & 2.16 & 4.24 & 4.35 & 2.69 \\
\hline CIP-392037-500 & & & & & & & & & & 3.88 & 3.32 & 5.09 & 4.16 \\
\hline HU1 & & & & & & & & & & & 4.26 & 4.31 & 2.85 \\
\hline HU14 & & & & & & & & & & & & 3.42 & 4.14 \\
\hline CIP-378371-19 & & & & & & & & & & & & & 3.72 \\
\hline Mean ED & 5.19 & 3.98 & 4.42 & 4.85 & 7.38 & 3.55 & 5.13 & 3.99 & 4.21 & 3.81 & 4.11 & 4.56 & 4.28 \\
\hline
\end{tabular}



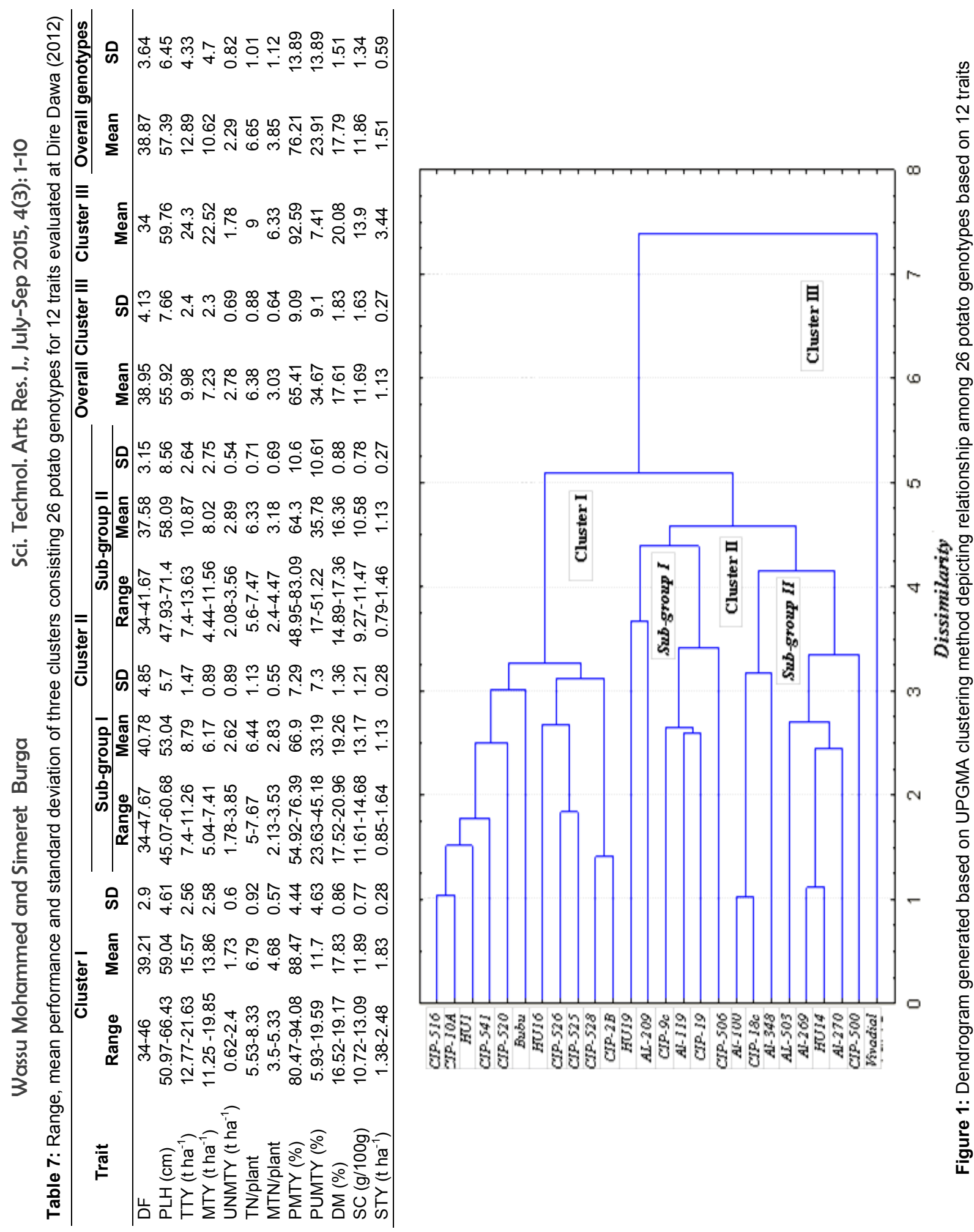
Wassu Mohammed and Simeret Burga

lower mean performance for all traits than overall mean of genotypes except days to $50 \%$ plants flowering, unmarketable tuber yield (t ha- $\left.{ }^{1}\right)$ and percent unmarketable tuber yield. Subgroup I in Cluster II was differentiated from Subgroup II with delayed flowering and higher mean values for tuber dry matter and starch content than overall mean values of genotypes. Vivadial had the highest mean values for all traits except for days to $50 \%$ plants flowering, unmarketable tuber yield $\left(\mathrm{t} \mathrm{ha}^{-1}\right)$ and percent unmarketable tuber yield (Table 7).

\section{DISCUSSION}

The presence of significant variation among 26 potato genotypes was observed from the analysis of variance results, and variability components (phenotypic and genotypic coefficients of variation, heritability and genetic advance as per cent of mean). This indicating the differences of genotypes for tuber yield, and other traits at lowland (high temperatures) were due to genetic differences. Potato is extensively adapted to cool temperatures and many authors reported that tuberization is significantly inhibited and photoassimilate partitioning to tubers is greatly reduced under high-temperature conditions (Ewing, 1981; Krauss and Marschner, 1984; Haynes et al., 1989; Lafta and Lorenzen, 1995; Van Dam et al., 1996; Rykaczewska, 2015). However, there are reports that indicate the existence of genetic variability for heat tolerance (Ewing et al., 1987; Levy et al., 1991; Rykaczewska, 2013), which is in agreement with the current study results. This showed that the higher chance of obtaining cultivars that are specifically adaptable to high temperatures for tuber production.

The highest tuber yield was obtained from one heat tolerant genotype and other four heat tolerant genotypes also produced reasonable higher tuber yield than most of the tested potato genotypes. However, two potato genotypes that were under maintenance and not identified as heat tolerant produced higher tuber yield than the four heat tolerant genotypes, while the improved potato variety (Bubu) produced tuber yield lower than heat tolerant genotypes. This might be due to the genetic differences of some genotypes in tolerating heat to produce tuber yield with minimum reduction while others failed due to high temperature. It was reported the existence of genetic control of heat tolerance (Levy et al., 1991) and certain genotypes have the capacity to initiate tubers at high temperatures (Ewing et al., 1987) and exhibit relatively small yield losses in hot seasons (Levy, 1986).

The mean dry matter and starch contents of tubers were 17.79 and $11.86 \%$, respectively, and considerable number of genotypes produced tubers as low as 14.89 and $9.27 \%$ dry matter and starch contents, respectively. Only three genotypes (two heat tolerant genotypes and one other) produced tubers with near to 21 and $14 \%$ dry matter and starch contents, respectively. This might be due to the effect of high temperatures that resulted competition of parts of plants for assimilates. When potato grow under high temperatures, it produced tall plants with long internodes, increased leaf and stem growth and more assimilates will be partitioned to foliage growth (Tsegaw et al., 2005). Therefore, at high temperatures accumulation of dry matter to tubers is restricted (Menzel, 1985; Kooman \& Haverkort, 1995), reduce specific gravity and reducing the total amount of starch incorporation into the tuber tissue (Thornton, 2001; Levy and Veilleux, 2007).
Sci. Technol. Arts Res. J., July-Sep 2015, 4(3): 1-10

This is due to reduced sink strength under high temperatures (Schafleinter et al., 2013). High dry matter content increases chip yield, crispy consistency, and reduces oil absorption during cooking (Pedreschi et al., 2005; Rommens et al., 2010). Potato cultivars with a dry matter content of $20 \%$ or higher, and starch content of $13 \%$ and above are the most preferred for processed products (Kirkman, 2007; Freitas et al., 2012). Therefore, only few potato genotypes were producing tubers suitable for processing, while others produced tubers suitable for boiling since they had tubers with low starch content (up to $12.0 \%$ ) (Esendal, 1990).

The phenotypic coefficient of variation was higher than genotypic coefficient of variation for all traits. According to the category of GCV and PCV proposed by Sivasubramanian and Menon (1973), both GCV and PCV values were high $(>20 \%)$ for all traits except both values were moderate for total tuber number per plant while moderate genotypic but high phenotypic coefficients of variations for unmarketable tuber yield and starch yield $t$ $\mathrm{ha}^{-1}$. On the other hand, as Robinson et al. (1949) and Johnson et al. (1955) suggested, both heritability and genetic advance as percent mean values were high for plant height, total and marketable tuber number per plant, tuber dry matter and starch contents. Moderate heritability was coupled either with high or moderate genetic advance as percent mean for all other traits except high heritability to moderate genetic advance for days to $50 \%$ plants flowering and low heritability was coupled with high genetic advance for unmarketable tuber yield $\mathrm{t} \mathrm{ha} \mathrm{h}^{-1}$. The observed high phenotypic and genotypic coefficient of variations for all the traits showed that the expressions of the traits were mainly the function of genetic factors. This in turn indicates the presence of substantial genetic variability among the tested potato genotypes. Though heritability of a character determines the extent to which it is transmitted from one generation to the next, heritability is a valuable tool when used in conjunction with genetic advance expectations from selection in predicting genetic gain that follows in the selection for that character (Ansari et al, 2004; Singh and Upadhyay, 2013). As suggested by Panse (1957) the observed high genetic advance coupled with high heritability is an indication of more additive gene action. Therefore, the improvement of the traits is possible through selection since high heritability was coupled with high genetic advance as percent mean.

The 26 potato genotypes exhibited large genetic distances under the prevalence of hot temperatures throughout the growing period. The heat tolerant genotype Vivadial formed a solitary cluster that might indicated the genetic selection of the genotype for the adaptation of high temperatures. On the other hand, the 11 potato genotypes grouped under Cluster I including the improved potato variety, and one heat tolerant genotype produced reasonably high total and marketable tuber yield up to 21.63 and $19.85 \mathrm{t} \mathrm{ha}^{-1}$, respectively, with relatively higher tuber dry matter and starch content. These genotypes can be considered for future breeding as far as their yield potential under heat stress is better than the average national potato yield $\left(<10 \mathrm{t} \mathrm{ha}^{-1}\right)$ for middle and high altitudes (Baye and Gebremedhin, 2013). The research result encourages the breeders to test large number of potato genotypes at lowland areas to develop cultivars adaptable to high temperatures. This suggestion is supported with other researchers that heat tolerance in 
Wassu Mohammed and Simeret Burga

potato is a function of genetic control (Levy et al., 1991), certain genotypes have the capacity to initiate tubers at high temperatures (Ewing et al., 1987) and exhibit relatively small yield losses in hot seasons (Levy, 1986).

\section{CONCLUSION}

Our study showed the presence of genetic variability among potato genotypes. It also showed the higher chance of selecting genotypes for high tuber yield with acceptable tuber quality through introduction of heat tolerant genotypes identified elsewhere in the world. This encourages potato breeders to introduce heat tolerant genotypes and test with the available materials in the country to develop varieties tolerant to heat.

\section{Conflict of Interest}

Conflict of interest none declared.

\section{Acknowledgments}

The authors thank Haramaya University and National Potato Improvement Project for the financial support, and technical staff of Horticulture Program at Haramaya University for their careful management of the experiment and data recording. Finally, the authors thank Dr. Tekaliegn Tsegaw, senior Horticulturist at Haramaya University who first showed the chance of developing heat tolerant potato cultivars in the country by providing the data collected from the experiment he conducted.

\section{REFERENCES}

Adane, H.M., Meuwissen, P.M., Agajie, T., M.Willemien, J., Lommen, A., Oude, L., Admasu, T. and Struik, P.C. (2010). Analysis of seed potato systems in Ethiopia. America Journal of Potato Research 87:537-552.

Allard, R.W. (1960). Principles of Plant Breeding. John Willy and Sons, Inc., New York, USA.

Ansari, K.A., Ansari, B.A. and Khund, A. (2004). Extent of heterosis and heritability in some quantitative characters of bread wheat. Indus Journal of Plant Science 3:189192.

AOAC (1980). Official Methods of Analysis. Association of Official Analytical Chemists (AOAC). AOAC International, $13^{\text {th }}$ Edtion, USD.

Arvin, M.J. and Donnelly, D.J.(2008). Screening potato cultivars and wild species to abiotic stresses using an electrolyte leakage bioassay. Journal of Agriculture Science Technology 10:33-42.

Bahari A., Pirdashti, H.and Yaghubi, M. (2013). The effects of amino acid fertilizers spraying on photosynthetic pigments and antioxidant enzymes of wheat (Triticum aestivum L.) under salinity stress. International Journal of Agronomy and Plant Production 4 (4):787-793.

Baye, B., and Gebremedhin, W. (2013). Potato research and development in Ethiopia achievements and trends. In: Gebremedhin, W., Schulz, S. and Baye, B. (eds.) Seed Potato Tuber Production and Dissemination: Experiences, Challenges and Prospects. Proceedings of the National Workshop on Seed Potato Tuber Production and Dissemination, 12-14 March 2012, Bahir Dar, Ethiopia. pp. 35-38.

Birch, P.R.J., Bryan, G., Fenton, B., Gilroy, E., Hein, I., Jones, J.T., Prashar, A., Taylor, M.A., Torrance, L. and Toth, I.K.. (2012). Crops that feed the world. Potato are the trends of increased global production sustainable. Food Security 4: 477-508.
Sci. Technol. Arts Res. J., July-Sep 2015, 4(3): 1-10

Brestic, M., Zivcak, M., Kalaji, M. H., Carpentier, R., Allakverdiev, S. I. (2012). Photosystem II thermo stability in situ: environmentally induced acclimation and genotype specific reactions in Triticum aestivum L. Plant Physiology and Biochemistry 57: 93-105.

Burton, G.A. and Devane, E.H. (1953). Estimation of heritability in tall festca (Festuca arundinacea) from replicated clonal materials. Agronomy Journal 45:478479.

CSA (Central Statistical Agency of Ethiopia).2009. Agriculture survey: Report on area and production crops, Addis Ababa, Ethiopia, p.126.

Esendal, E. (1990). Potato. University of Ondokuz Mayis, Faculty of Agriculture, No: 49. ISBN: 975-7636-06-1, Samsun, Turkey, p 221.

Ewing E. E. (1981). Heat stress and tuberization stimulus. America Journal of Potato 8:31-49.

Ewing, E.E., Lorenzen, J.H., Reynolds, M.P., Gebre-Marian, S., Snyder, R.G. and Ben Khedher, M. (1987). Evaluating heat tolerance in potato. In: W.N. Chang, P.W. MacGregor and J. Bay-Peterson (Eds.), Improved Vegetable Production in Asia. Food and Fertilizer Technology Center, Taipei, Book Series No. 36, pp. 110118.

Falconer, D.S. (1990). Introduction to Quantitative Genetics (3rd edition). John Wiley and Sons, Inc., New York, USA.

FAO. (2009). How to feed the World in 2050. Paper prepared for how to feed the World in 2050 presented for high level expert forum, 12-13 October 2009, Rome available at www.fao.org/fileadmin/templates/wsfs/docs/expert_paper/ How_to_Feed_the_World_in_2050.

Freitas, S. T., Pereira, E.I.P., Gomez, A.C.S., Brackmann, A., Nicoloso, F. and Bisognin, D.A. (2012). Processing quality of potato tubers produced during autumn and spring and stored at different temperatures. Horticultura Brasileira 30: 91-98.

Hailay, D.T., Lipsitch, M., Awash, T. and Schwartz, J. (2004). Weather-based prediction of Plasmodium falciparum malaria in epidemic-prone regions of Ethiopia I. Patterns of lagged weather effects reflect biological mechanisms. Malaria Journal 3 (41):1-11.

Hancock, R.D., Morris, W.L., Ducreux, L.J.M., Morris, J.A. Usman, M., Verrall, S.R., Fuller, J., Simpson, C.G., Zhang, R., Hedley, P.E. and Taylor, M.A. (2014) Physiological, biochemical and molecular responses of the potato (Solanum tuberosum L.) plant to moderately elevated temperature. Plant Cell Environment 37:439450.

Haynes, K.G., Haynes, F.L. and Henderson, W.R. (1989) Heritability of specific gravity of diploid potato under hightemperature growing conditions. Crop Sciences 29:622625.

Hijmans R.J. (2003). The effect of climate change on global potato production. America Journal of Potato Research 80:271-280

Johnson, H.W., Robinson, H.F. and Comstock, R.E. (1955). Estimates of genetic and environmental variability in soybeans. Agronomy Journal 47:314-318.

Kalaji, M.H., Bosa, K., Kościelniak, J. and Hossain, Z. (2011). Chlorophyll a fluorescence a useful tool for the early detection of temperature stress in spring barley (Hordeum vulgare L.). International Journal of Integrative Biology 15(12): 925-934. 
Wassu Mohammed and Simeret Burga

Kirkman, M.A. (2007). Global markets for processed potato products. In: D. Vreugdenhil, (Ed.). Potato Biology and Biotechnology Advances and Perspectives. Elsevier, Oxford, pp. 27-44.

Kooman, P.L. and Haverkort, A.J. (1995). Modeling development and growth of the potato crop influenced by temperature and day length. In: A.J. Haverkort and D.K.... MacKerron (eds.), Potato Ecology and Modeling of Crop under Conditions Limiting Growth. Kluwer Academic Publishers, Dordrecht, pp. 41-59.

Krauss, A. and Marschner, H. (1984). Growth rate and carbohydrate metabolism of potato tubers exposed to high temperatures. Potato Research 27:297-303.

Kyamanywa, S., Kashaija, I., Getu, E., Amata, R., Senkesha, N. and Kullaya, A. (2011).Enhancing Food Security through Improved Seed Systems of Appropriate Varieties of Cassava, Potato and Sweet potato Resilient to Climate Change in Eastern Africa. Nairobi, Kenya, ILRI.

Lafta, A.H. and Lorenzen, J.H. (1995). Effect of high temperature on plant growth and carbohydrate metabolism in potato. Plant Physiology 109:637-643.

Levoyageur Weather. (2012). http://en.wikipedia.org/w/index (Accessed on July 11, 2012).

Levy, D. (1986). Genotypic variation in the response of potatoes (Solanum tuberosum L.) to high ambient temperatures and water deficit. Field Crops Research 15:85-96.

Levy, D., and Veilleux, E.R. (2007). Adaptation of Potato to High Temperatures and Salinity - A Review. American Journal of Potato Research 84: 487-506.

Levy, D., Kastenbaum, E. and Itzhak, Y. (1991). Evaluation of parents and selection for heat tolerance in the early generations of a potato (Solanum tuberosum L.) breeding program. Theoretical and Applied Genetics 82:130-136.

Menzel, C.M. (1985). Tuberization in potato (Solanum tuberosum cultivar Sebago) at high temperatures: Interaction between temperature and irradiance. Annual Botany 52:35-39.

Panse, U.G. (1957). Genetics of quantitative characters in relation to plant breeding. Indian Journal of Genetics 17: 318-328.

Pedreschi, F., Moyano, P., Kaack, K. and Granby, K.( 2005). Color changes and acrylamide formation in fried potato slices. Food Research International 38: 1-9.

Robinson, H. F., Comstock, R. E. and Harvery, V. H. (1949). Estimates of heritability and degree of dominance in corn. Agronomy Journal 41: 353-359.

Rommens, C.M., Shakya, R., Heap, M. and Fessenden, K. (2010). Tastier and healthier alternatives to French fries. Journal of Food Science 75:109-115.

Rykaczewska, K. (1993). Effect of temperature during growing season and physiological age of minitubers on
Sci. Technol. Arts Res. J., July-Sep 2015, 4(3): 1-10

potato plant development and yield. Bull Potato Institute 42:39-46.

Rykaczewska, K. (2015). The Effect of high temperature occurring in subsequent stages of plant development on potato yield and tuber physiological defects. America Journal of Potato Research 92:339-349.

Rykaczewska, K. (2013). The Impact of high temperature during growing season on potato cultivars with different response to environmental stresses. American Journal of Plant Sciences 4: 2386-2393.

SAS (2004). Institute Inc., "SAS. 9.1. Companion for Windows," SAS Publishing, SAS Institute Inc., Cary.

Schafleitner, R., Bonierbale, M. and Tay, D. (2013). Photosynthetic efficiency and its impact on yield in potato. In: J.E. Gready, S.A. Dwyer and J.R. Evans (Eds.), Applying Photosynthesis Research to Improvement of Food Crops. Proceedings of a workshop held at the Australian National University, Canberra, Australia, 2-4 September 2009, AICAR Proceedings Series, pp. 52-60.

Singh, B. and Upadhyay, P.K..(2013).Genetic variability, correlation and path analysis in wheat (Triticum aestivum L.). Indian Research Journal of Genetics and Biotechnology 5(3): 197-202.

Sivasubramanian, S. and Menon, M. (1973). Heterosis and inbreeding depression in rice. Madras Agricultural Journal 60: 1139.

Sneath, P.H., Sokal, R.R. (1973). Numerical Taxonomy. Freeman and Company, San Francisco, USA.

STATISTICA 7 Software. (2002). StatSoft Revision 06/03/03,U.S.A.

Struik, P.C., Geertsema J. and Custers, C.H.M.G. (1989). Effect of shoot, root and stolon temperature on the development of the potato (Solanum tuberosum $\mathrm{L}$ ) plant. III. Development of tubers. Potato Research 32:151-158.

Tai, G.C.C. and Coleman, W. (1999). Genotype environment interaction of potato chip color. Canada Journal of Plant Sciences 79:433-438.

Tsegaw, T., Hammes, P.S. and Robberste, J. (2005). Paclobutrazol induced leaf, stem and root anatomical modifications in potato. Horticulture Science 40(5):13451346.

Thornton, K.M. (2001). Effects of heat and water stress on the physiology of potatoes. Idaho Potato Conference 2002. Annual Botany 45:33-35.

Vandam, J., Kooman, P.L. and Struik, P.C. (1996). Effects of temperature and photoperiod on early growth and final number of tubers in potato (Solanum tuberosum L.). Potato Research 39:51-62.

William, M.A. and Woodbury, G.W. (1968). Specific gravity dry matter relationship and reducing sugar change affected by potato variety, production area and storage. American Potato Journal 45 (4):119-131. 